\title{
BEBAN DAN KOPING CAREGIVER LANSIA DEMENSIA DI PANTI WREDHA
}

\author{
Rita Hadi Widiastuti ${ }^{1}$, Anissa Ika setyowati Setyowati², Dika Ekivalent Setianingrum ${ }^{3}$ \\ ${ }^{1}$ Dosen Divisi Keperawatan Jiwa dan Komunitas, Departemen Ilmu Keperawatan, Fakultas Kedokteran, \\ Universitas Diponegoro \\ ${ }^{2}$ Mahasiswa Departemen Ilmu Keperawatan, Fakultas Kedokteran, Universitas Diponegoro \\ ${ }^{3}$ Mahasiswa Departemen Ilmu Keperawatan, Fakultas Kedokteran, Universitas Diponegoro \\ E-Mail :ritahadi@fk.undip.ac.id
}

\begin{abstract}
ABSTRAK
Lansia demensia memiliki perubahan dalam aspek fisik, psikologis, aktivitas sehari-hari, hubungan sosial dan kualitas hidup. Perubahan pada lansia demensia menyebabkan timbulnya situasi stress pada caregiver, sehingga berisiko mengalami beban. Adanya masalah ini, maka penggunaan strategi koping Problem Focused Coping (PFC) maupun Emotional Focused Coping (EFC) diperlukan untuk menghadapi situasi stres sehingga dapat mengurangi beban caregiver. Penelitian ini bertujuan untuk mengetahui beban caregiver dan strategi koping caregiver lansia demensia di panti wredha. Metode penelitian yang digunakan adalah penelitian kuantitatif deskriptif dengan pendekatan cross sectional. Teknik sampling yang digunakan yaitu consecutive sampling dengan jumlah sampel 82 responden. Hasil penelitian dianalisis menggunakan analisa univariat dalam bentuk tabel distribusi frekuensi. Hasil menunjukkan bahwa beban caregiver yaitu beban ringan sebanyak $56,7 \%$, beban sedang sebanyak $24,4 \%$ dan caregiver mengalami beban berat sebanyak 16,6\% sedangkan strategi koping caregiver yaitu 52,4\% caregiver menggunakan PFC dengan domain yang paling sering digunakan yaitu planful problem dan 47,6\% caregiver menggunakan EFC dengan domain yang sering digunakan seeking social support, accepting responsibility, dan postive reappraisal. Berdasarkan penelitian diharapkan perawat mampu memberikan bimbingan/konseling dan pelatihan untuk caregiver, diharapkan panti wredha mampu menjadi fasilitator dalam memasukkan support group therapy dalam jadwal rutin.
\end{abstract}

Kata kunci: Beban, Caregiver, Koping, Demensia

\section{LOADS AND KOPING CAREGIVER ELDERLY DEMENSIA IN ELDERLY RESEARCH}

\begin{abstract}
Dementia causes the changes of physicals, psychological, daily activities, social relationships and quality of life. The changes of elderly dementia cause a stressful situation for the caregiver, so it has risks of getting burden. The use of coping strategies with Problem Focused Coping (PFC) and Emotional Focused Coping (EFC) methods is needed to deal with the stressful situations so it can reduce the caregiver's burden. The purpose of this study was to find out the coping strategies of elderly dementia caregiver at wredha home. The research method used was descriptive quantitative research with cross sectional approach. The sampling technique used was consecutive sampling with the total sample of 82 respondents. The results of the study were analyzed using univariate analysis in the form of frequency distribution tables. The results showed that level of caregiver burden are light burden 56,7\%, medium burden 24,4\% and high burden 16,6\%, futhermore coping strategy of caregiver are $52.4 \%$ of caregivers using PFC with the most frequently used domains were planful problems and $47.6 \%$ of caregivers using EFC with domains that were often used seeking social support, accepting responsibility, and postive reappraisal. Based on the research are capable of providing guidance/counseling and tranining for caregivers. For nursing home it is expected to be a facilitator in entering support group therapy in a regular schedule.
\end{abstract}

Keywords: Burden, Caregiver, Coping, Dementia 


\section{PENDAHULUAN}

Lanjut usia (lansia) mengalami kemunduran fisik, sosial, dan psikologi secara bertahap dan mengakibatkan masalah kesehatan. Masalah psikologi yang sering dialami lansia salah satunya demensia (Azizah, 2011). Di Indonesia, jumlah Orang dengan demensia (ODD) diperkirakan akan makin meningkat dari . 960.000 di tahun 2013, menjadi 1.890 .000 di tahun 2030 dan 3.980.000 ODD di tahun 2050 (World Report Alzheimer, 2012), sementara itu proporsi lanjut usia di tiga wialayah ( DKI Jakarta, Jawa Barat dan Jawa Tengah) yang mengalami penurunan kognitif sebanyak $38,9 \%$, sedangkan yang mengalami demensia sekitar 4\% (Hogervorst et al.,2009). Perubahan yang terjadi pada lansia demensia meliputi perubahan tingkah laku seperti delusi, halusinasi, depresi, kerusakan fungsi tubuh, cemas, disorientasi spasial, ketidakmampuan melakukan tindakan yang berarti, tidak dapat melakukan aktivitas sehari-hari secara mandiri, melawan, marah, agitasi, apatis dan kabur dari tempat tinggal (Miller, 2004). Adanya perubahan pada ODD, caregiver memiliki peranan penting dalam perawatan lansia di panti wredha (Triwanti \& Gutama, 2014). Fazio menyatakan bahwa hampir $60 \%$ lansia dengan demensia tinggal di panti dan hanya 25\% yang tinggal sendiri (Fazio, Pace, Maslow, Zimmerman, \& Kallmyer, 2018).

Caregiver memberikan berbagai macam perawatan dan menghabiskan rata-rata 28 jam per minggu untuk memberikan perawatan aktivitas sehari-hari (Activities of Daily Living) kepada lansia dengan demensia. Hampir 80\% lansia dengan demensia memerlukan bantuan untuk perawatan diri rutin seperti mandi, memakai pakaian, merias diri, hingga makan. Satu dari tiga caregiver memberikan bantuan dalam mandi, menyuapi, dan membantu lansia untuk pergi dan kembali dari toilet. Alzheimer's Association dan National Alliance for Caregiving dan Yuliawati menyatakan bahwa terdapat perbedaan yaitu tanggung jawab dan penambahan jumlah waktu pada caregiver demensia dibandingkan dengan caregiver non-demensia (Alzheimer's Association \& National Alliance for Caregiving, 2004; Yuliawati AD. Handadari, 2013). Penatalaksanaan ODD dapat menimbulkan beban bagi caregiver yang meliputi : beban fisik, beban psikologis, beban ekonomi dan beban psikososial
(Widyastuti,R.H.,Sahar,J.,\& Permatasari,H., 2011). Penelitian Mohamed S, Rosenheck R, dan Lyketsos $\mathrm{K}$ menguraikan bahwa masalah perilaku, psikiatri dan penurunan kualitas hidup pada ODD berhubungan dengan tingkat caregiver burden dan depresi pada caregiver (Mohamed S, Rosenheck R, Lyketsos K, 2014).

Beban caregiver dapat berdampak pada kesehatan fisik, mental, sosial dan ekonomi pengasuh itu sendiri (Putri, 2013; Zawadzki et al., 2011).Beban fisik yang dialami caregiver berhubungan erat dengan tingginya aktivitas sehari-hari yang dilakukan lansia (Miyamoto, Tachimori, \& Ito, 2010).Caregiver mengalami keletihan dan kelelahan fisik karena membantu aktivitas lansia. Beban ekonomi terjadi apabila caregiver memiliki tanggung jawab finansial untuk lansia dimana hal tersebut berkaitan erat dengan beban yang lebih tinggi (Andrén \& Elmståhl, 2007). Selain itu, caregiver lansia demensia juga mengalami beban psikologis yangberhubungan dengan timbulnya kondisi gejala depresi, agresivitas dan ansietas dibandingkan dengan caregiver non-demensia (Alfakhri et al., 2018; Cheng, 2017).Oleh karena itu, maka perlu adanya strategi koping yang digunakan oleh caregiver. Sumber Koping dari caregiver terdiri kesatuan yang komplek dan dinamik dari respon kognitif, afektif dan psikomotor yang bertujuan untuk meregulasi emosi, mengatasi dan meningkatkan kemampuan mengatasi masalah, dan mempertahankan kekuatan psikologi sehingga tetap dapat memberikan perawatan yang efektif dalam jangka waktu yang panjang (Gottlieb \& Wolfe, 2002). Strategi koping negatif menyebabkan meningkatnya hormon kortisol steroid, hormon eprinefrin dan noneprinefrin yang jika dikeluarkan secara terus-menerus menyebabkan kerusakan pada tubuh, misalnya gangguan pencernaan hingga penyakit jantung. Strategi koping yang positif yaitu Problem Focused Coping dapat menurunkan tingkat stres dan depresi yang dialami caregiver (Jeffrey \& Nevid, 2002).

\section{METODE}

Penelitian ini merupakan jenis penelitian dengan desain deskriptif survei, menggunakan metode kuantitatif, dan pendekatan crosssectional. Responden penelitian ini terdiri dari 82 orang caregiver di Panti Wreda Di Kota Semarang yang meliputi 3 Panti Wreda di Kota 
Semarang. Teknik sampling dengan menggunakan metode consecutive sampling dengan kriteria inklusi; caregiver usia $\geq 18$ tahun, bekerja di panti wredha, dan terlibat perawatan sehari-hari lansia demensia. Penelitian mendapatkan persetujuan dari Komite Etik Penelitian Fakultas Kedokteran Universitas Diponegoro dengan nomor 330/EC/FK-RSDK/IV/2017. Variabel penelitian ini adalah data demografi, tingkat caregiver burden dan strategi koping caregiver lansia demensia.

Teknik pengumpulan data dengan menggunakan kuesioner. Data karakteristik menggunakan kuesioner data demografi yang meliputi jenis kelamin, usia, pendidikan dan agama.

Caregiver burden diukur menggunakan kuesioner Zarit Burden Scale yang dikembangkan oleh Zarit (Zarit, Reever, \& Bach-Peterson, 1980) terdiri dari 22 pertanyaan tentang caregiver yang meliputi kesehatan, psychological wellbeing, keuangan, kehidupan sosial dan hubungan antara caregiver dengan lansia dengan demensia.

Startegi koping Caregiver diukur dengan menggunakan kuesioner The Ways of Coping yang terdiri dari 50 pertanyaan untuk penggunaan strategi koping. The Ways of Coping disusun oleh Lazarus dan Folkman. Kuesioner ini terdiri dari 50 pertanyaan dan memiliki dua aspek utama yaitu penyelesaian masalah yang berfokus pada masalah (Problem Focused Coping) dan penyelesaian masalah yang berpusat pada emosi (Emotional Focused Coping). Bentuk strategi koping Problem Focused Coping yaitu confrontative coping dan planfull problem solving, sedangkan bentuk strategi koping Emotion Focused Coping yaitu distancing, self control, seeking social support, accepting responsibility, escape avoidance dan positive reappraisal (Lazarus, F., 1987).

\section{HASIL PENELITIAN}

\section{A. Karakteristik caregiver}

Tabel 1. Distribusi Frekuensi Data Demografi Caregiver Lansia Demensia di Panti Wredha $(\mathbf{n}=\mathbf{8 2})$

\begin{tabular}{llll}
\hline & Data Demografi & Frekuensi & Presentase (\%) \\
\hline \multirow{2}{*}{ Jenis Kelamin } & Laki-laki & 28 & 34,1 \\
& Perempuan & 54 & 65,9 \\
\multirow{3}{*}{ Usia } & $18-40$ tahun & 7 & 24,4 \\
& 40-60 tahun & 14 & 61,0 \\
& $>60$ tahun & 18 & 14,6 \\
\hline \multirow{4}{*}{ Pendidikan } & & & \\
& SMP & 11 & 13,4 \\
& SMA/SMK & 56 & 68,3 \\
\multirow{4}{*}{ Agama } & Perguruan Tinggi & 15 & 18,3 \\
& Islam & 52 & 63,4 \\
& Katolik & 21 & 25,6 \\
& Kristen & 9 & 11,0 \\
\hline
\end{tabular}

Tabel 1 menunjukkan bahwa dari 82 responden dengan karakteristik responden didapatkan hasil presentase terbesar yaitu berjenis kelamin perempuan dengan jumlah 65,9\%, usia 40-60 tahun dengan jumlah $61,0 \%$, pendidikan formal caregiver adalah SMA dengan jumlah 68,3\%, dan agama yang dianut adalah Islam dengan jumlah $63,4 \%$ responden.

\section{B. Beban Caregiver}

Tabel 2. Distribusi Frekuensi Tingkat Beban Caregiver Lansia Demensia di Panti Wredha $(n=$ 82)

\begin{tabular}{|c|c|c|c|}
\hline & Variabel & Frekuensi (n) & Persentase (\%) \\
\hline \multicolumn{4}{|c|}{ Beban caregiver } \\
\hline a. & Tidak ada beban & 6 & 7,3 \\
\hline b. & Beban Ringan & 44 & 56,7 \\
\hline c. & Beban Sedang & 20 & 24,4 \\
\hline d. & Beban Berat & 12 & 16,6 \\
\hline Jun & & 82 & 100 \\
\hline
\end{tabular}




\section{Strategi Koping caregiver}

Tabel 3. Distribusi Frekuensi Strategi Koping Caregiver Lansia Demensia di Panti Wredha $(\mathbf{n}=\mathbf{8 2})$

\begin{tabular}{cccc}
\hline No & Strategi Koping & Frekuensi (f) & Presentase (\%) \\
\hline 1 & Problem focused coping & 43 & 52,4 \\
2 & Emotional focused coping & 39 & 47,6 \\
\hline & Jumlah & 82 & 100 \\
\hline
\end{tabular}

Tabel 2 menunjukkan strategi koping caregiver lansia demensia di Panti Wredha didapatkan bahwa sebagian besar responden menggunakan Problem Focused Coping sebanyak 52,4\%

\section{Domain Strategi Koping caregiver}

Tabel 4. Distribusi Frekuensi Domain Strategi Koping Caregiver Lansia Demensia di Panti

Wredha $(\mathbf{n}=82)$

\begin{tabular}{|c|c|c|c|}
\hline No & Keterangan & Frekuensi (f) & Presentase (\%) \\
\hline \multirow[t]{3}{*}{1} & Confronting coping & & \\
\hline & Digunakan & 34 & 41,46 \\
\hline & Tidak digunakan & 48 & 58,54 \\
\hline \multirow[t]{3}{*}{2} & Planful problem & & \\
\hline & Digunakan & 45 & 54,88 \\
\hline & Tidak digunakan & 38 & 46,34 \\
\hline \multirow[t]{3}{*}{3} & Distancing & & \\
\hline & Digunakan & 31 & 37,80 \\
\hline & Tidak digunakan & 51 & 62,19 \\
\hline \multirow[t]{3}{*}{4} & Self-controling & & \\
\hline & Digunakan & 35 & 42,68 \\
\hline & Tidak digunakan & 47 & 57,32 \\
\hline \multirow[t]{3}{*}{5} & Seeking social support & & \\
\hline & Digunakan & 44 & 53,66 \\
\hline & Tidak digunakan & 38 & 46,34 \\
\hline \multirow[t]{3}{*}{6} & Accepting responsibility & & \\
\hline & Digunakan & 50 & 60,98 \\
\hline & Tidak digunakan & 32 & 39,02 \\
\hline \multirow[t]{3}{*}{7} & Escape avoidance & & \\
\hline & Digunakan & 38 & 46,34 \\
\hline & Tidak digunakan & 45 & 55,88 \\
\hline \multirow[t]{3}{*}{8} & Positive reappraisal & & \\
\hline & Digunakan & 48 & 58,54 \\
\hline & Tidak digunakan & 34 & 41,46 \\
\hline
\end{tabular}

Tabel 3 menunjukkan bahwa domain strategi koping yang mayoritas digunakan caregiver adalah planful problem (54,88\%), seeking social support (53,66\%), accepting responsibility (60,98\%), dan positive reappraisal $(58,54 \%)$. Domain strategi koping mayoritas yang tidak digunakan caregiver yaitu confronting coping $(58,54 \%)$, distancing $(62,19 \%)$, self-controling $(57,32 \%)$, dan escape avoidance $(55,88 \%)$.

\section{PEMBAHASAN}

\section{A. Karakteristik Responden}

Hasil penelitian menunjukkan bahwa caregiver lansia demensia di panti wredha paling banyak berusia dewasa tengah (40-60 tahun) sebanyak $35,4 \%$. Kelompok dengan usia dewasa muda hingga usia dewasa tengah lebih banyak menggunakan Problem Focused Coping
(Lazarus, 1987). Perbedaan dalam pemilihan strategi koping dikaitkan dengan sumber stres pada kelompok usia dewasa tengah, dimana usia dewasa tengah lebih menata kembali kehidupan keluarga karena anak-anaknya berubah menjadi lebih mandiri dan siap untuk meninggalkan rumah, berkontribusi kepada masyarakat, dan membantu generasi mendatang. Tugas baru inilah yang akan 
menjadikan beban pikiran dalam mengerjakan pekerjaannya, sehingga lebih rentan terhadap stres. Namun, di usia dewasa tengah individu masih memiliki kekuatan dan kemampuan untuk menghadapi serta mampu membuat rencana untuk menghadapi stressornya sehingga lebih cenderung memilih strategi koping dengan Problem Focused Coping (Ashley, Kleinpeter, \& Hagan, 2008).

Presentase jenis kelamin caregiver dalam penelitian ini yaitu perempuan sebesar $65,9 \%$. Perempuan cenderung lebih berisiko mengalami beban dan stress jika dibandingkan laki-laki. Akan tetapi, perempuan memiliki kemampuan fisik, mengendalikan diri, peran sosial, peduli, sabar, sosialisasi dan tingkat adaptasi yang tinggi jika dibandingkan lakilaki ketika merawat lansia. Sehingga cenderung menggunakan Problem Focused Coping (Ashley, Kleinpeter, \& Hagan, 2008).

Tingkat pendidikan tertinggi yang dimiliki caregiver dalam penelitian ini yaitu SMA/SMK sebanyak 68,3\%. Ketrampilan, pendidikan, dan pengalaman sangat mempengaruhi caregiver dalam proses pengambilan keputusan dalam merawat lansia demensia. Individu yang memiliki pendidikan lebih tinggi akan menilai segala sesuatu lebih realistis, individu ini lebih memilih menerima keadaan apa adanya dan bersikap postif terhadap stressor yang dimiliki serta segera mencari beberapa solusi untuk mengatasi stressor. Oleh karena itu individu dengan tingkat pendidikan tinggi cenderung menggunakan Problem Focused Coping (Smrtnik \& Prosen, 2016).

Presentase agama yang dianut oleh responden adalah Islam yaitu sebanyak $63,4 \%$. Caregiver menggunakan kemampuan religiusitas untuk mengatasi stressor yang dialami caregiver. Salah satu yang dapat dilihat dari tingkat religiusitas individu adalah frekuensi dalam berdoa dan menganggap agama adalah hal yang paling penting dalam hidup. Tingkat spiritualitas yang tinggi berpengaruh dalam aspek psikologis, kesehatan diri, dan dapat mengurangi beban (Nagpal, Heid, Zarit, \& Whitlatch, 2015).

\section{B. Beban Caregiver}

Perubahan perilaku dan ketergantungan dalam jangka panjang akibat demensia dapat menimbulkan peningkatan beban subjektif maupun objektif pada caregiver ( Sun, F.,
Kosberg, Leeper, Kaufman, \& Burgio, 2010).Hasil penelitian Putri menggambarkan bahwa gangguan memori pada lansia demensia berhubungan dengan beban merawat dan tingkat depresi caregiver (Putri, 2013). Stressor pada pemberi perawatan atau caregiver disebut dengan stressor caregiving. Stressor caregiving terdiri dari beberapa komponen yaitu stressor objektif, subjektif, dan ketegangan peran seperti gangguan akibat perilaku, ketidakmampuan pemberian perawatan secara optimal, dan ketidakpuasan dalam merawat. Hubungan ini bersifat timbal baik karena perubahan emosi dan perilaku lansia juga dapat menimbulkan dampak respon negatif pada caregiver yang merawat lansia berupa caregiver burden (Prabasari, Juwita, \& Maryuti, 2017).

Faktor-faktor yang dapat mempengaruhi terjadinya beban caregiver (caregiver burden) yaitu usia, jenis kelamin, tingkat pendidikan, dan pekerjaan. Hasil penelitian menunjukkan bahwa seluruh caregiver di Panti Wredha tergolong dalam kategori usia dewasa menengah yang berkisar antara 40-56 tahun. Usia dewasa menengah ini rawan terjadinya beban perawatan apabila tidak memiliki kemampuan dalam memaknai hidup. Beban atau stress berlebihan pada perawatan ini juga akan berdampak pada psikologis dari caregiver, khususnya caregiver perempuan.

Hasil penelitian ini menunjukkan bahwa caregiver berjenis kelamin perempuan lebih banyak dibandingkan dengan laki-laki. Hal ini sesuai dengan penelitian Zawadzki bahwa mayoritas caregiver yang merawat lansia demensia adalah perempuan, dimana perempuan lebih erat kaitannya dengan mengasuh atau merawat dan termasuk kedalam tatanan sosial dengan kategori kepedulian tinggi dibandingkan dengan laki-laki (Zawadzki et al., 2011). Kim et al menyatakan bahwa sebenarnya perempuan lebih rentan terhadap terjadinya beban perawatan (caregiver burden) saat merawat lansia dengan demensia dibandingkan dengan laki-laki (Kim et al., 2009).Caregiver khususnya perempuan dengan tingkat pendidikan rendah berisiko mengalami beban yang lebih tinggi dibandingkan dengan lulusan tingkat pendidikan tinggi (Truong, 2015).

Lebih dari setengah $(56,7 \%)$ caregiver memiliki pendidikan tingkat menengah. Truong yang menyatakan bahwa caregiver 
dengan tingkat pendidikan sarjana akan lebih rendah terjadinya risiko beban perawatan (Truong, 2015). Caregiver dengan lulusan pendidikan tinggi juga memiliki kemampuan dalam pengelolaan masalah, mampu memiliki kemampuan mengelola stress dengan efektif (Papastavrou, Kalokerinou, Papacostas, Tsangari, \& Sourtzi, 2007). Mayoritas caregiverdi Panti Wredha berstatus Pegawai Negeri Sipil (PNS) sebanyak 76,7\%. Caregiver yang bekerja di Panti Wredha tidak hanya perawat, bahkan mayoritas bukan lulusan perawat atau disebut dengan pekerja sosial. Oleh karena itu, caregiver tidak mengalami beban ekonomi saat merawat lansia dengan demensia. Seluruh biaya kebutuhan dari lansia demensia ditanggung sepenuhnya oleh Dinas Sosial, sehingga caregiver tidak mengeluarkan biaya apapun untuk memenuhi kebutuhan lansia demensia terkait keuangan.

Beban akan terasa ringan apabila diberikan upaya berupa intervensi, sesuai dengan penelitian Sugiyama yang menyatakan bahwa psychotherapy group efektif untuk menurunkan beban pada caregiver lansia demensia (Sugiyama, Kasanuki, Yamagata, Sato, \& Ichimiya, 2017). Intervensi dengan prinsip konseling, psychoeeducation, dan familyassociation menjadi dasar untuk meringankan beban yang dirasakan oleh caregiver. Beberapa caregiver yang tidak terpapar intervensi dapat mentoleransi dan mampu beradaptasi sehingga dapat terbentuk koping positif (Yuniati, 2017). Hal ini sesuai dengan model adaptasi Roy dari Sister Callista Roy, dimana setiap orang dapat menggunakan koping positif maupun koping negatif saat beradaptasi dengan penyebab terjadinya perubahan dan pengalaman beradaptasi (Kathleen Masters, 2015).

\section{Strategi Koping Caregiver}

Hasil penelitian menunjukkan bahwa mayoritas caregiver lansia demensia di panti wredha menggunakan strategi koping Problem Focused Coping (PFC) yaitu sebanyak 52,4\%. Penggunaan PFC sejalan dengan penelitian Tschanz JT et al, yang didapatkan nilai mean (SD) PFC yaitu 1,99 $(0,55)$ (Ashley et al., 2008). Strategi koping jenis ini yaitu cara menanggulangi stress dengan berfokus pada permasalahan yang dihadapi. Strategi koping dengan cara ini dilakukan untuk menghindari atau mengurangi stres dengan cara langsung menghadapi sumber stres (Lazarus, 1987). PFC mempengaruhi respon fisik caregiver, yaitu hemostasis khususnya respon proagulan dan menurunkan risiko penyakit kardiovaskular pada caregiver. Ketika individu mengalami stressor akut akan menyebabkan ruptur plak dan secara bersamaan akan meningkatkan trombus arteri koroner. Akumulasi stressor akut dalam jangka lama akan menimbulkan bahaya bagi kesehatan individu, misalnya aterosklerosis atau kerusakan endotel (Aschbacher, et al, 2005). Upaya yang dapat dilakukan perawat yaitu dengan support group therapy (Baker \& Berenbaum, 2008).

Penggunaan strategi koping lainnya adalah dengan menggunakan Emotional Focused Coping (EFC). Berdasarkan hasil penelitian didapatkan $47,6 \%$ caregiver yang menggunakan EFC. EFC adalah cara individu dengan berusaha untuk segera mengurangi dampak stressor, biasanya dengan cara menyangkal adanya stresor atau menarik diri dari situasi. Namun koping yang berfokus pada emosi tidak tidak menghilangkan stresor dan tidak juga membantu individu dalam mengembangkan cara yang lebih baik untuk mengatur stresor (Lazarus, 1987). Dampak pada tubuh caregiver dimana ketika stressor maupun beban tidak bisa teratasi maka hormon kortisol steroid, eprinefrin dan noneprinefrin meningkat. Apabila hormon tersebut dikeluarkan terus-menerus menyebabkan kerusakan pada tubuh, misalnya gangguan pencernaan hingga penyakit jantung (Ali S, 2015). Upaya yang dapat dilakukan yaitu bimbingan konseling kepada caregiver yang dapat membangun hubungan saling percaya antara caregiver, sehingga dapat mempermudah perawat menemukan penyebab caregiver menggunakan strategi koping maladaptif (Watson, 2017).

Analisa deskriptif domain confronting coping menunjukkan bahwa $58,54 \%$ responden cenderung tidak menggunakan domain ini. Confronting coping merupakan suatu bentuk strategi koping dengan cara bereaksi untuk mengubah keadaan yang dapat menggambarkan tingkat risiko yang harus diambil (Lazarus, 1987). item pertanyaan yang paling banyak tidak dipilih adalah menunjukkan kemarahan kepada lansia demensia. Hal ini disebabkan karena adanya 
peraturan dari panti wredha untuk tetap memberikan pelayanan yang maksimal. Penelitian yang dilakukan oleh Papastavrou et all didapatkan bahwa penggunaan confronting coping mempengaruhi tingkat depresi caregiver ketika merawat lansia demensia dikarenakan caregiver lebih percaya diri terhadap kemampuannya untuk menangani lansia demensia secara efektif dan mengurangi dampak negatif yang timbul dari perawatan yang diberikan (Papastavrou et al., 2011).

Hasil penelitian menunjukkan 54,88\% caregiver menggunakan domain Planfull Problem. Koping ini adalah cara individu mengatasi stress dengan melakukan usahausaha tertentu yang bertujuan untuk mengubah keadaan, diikuti pendekatan analitis dalam menyelesaikan masalah (Lazarus, 1987). Item pertanyaan yang sering digunakan caregiver adalah membuat rencana kegiatan dan mengaplikasikan kepada lansia demensia. Penelitian menyatakan bahwa penggunaan planful problem berkaitan dengan hemostatik tubuh, khususnya respon proagulan dan menurunkan risiko penyakit kardiovaskular pada caregiver, dikarenakan timbulnya penyakit kardiovaskular disebabkan adanya tumpukan beban dan stressor berlebih yang menyebabkan ruptur plak endotel (Aschbacher K, Patterson TL, von Känel R, Dimsdale JE, Mills PJ, Adler KA, Ancoli-Israel S, 2005).

Hasil penelitian menunjukkan 62,19\% caregiver tidak menggunakan domain distancing. Distancing adalah suatu cara yang dapat dilakukan individu dengan menjaga jarak agar tidak terbelenggu oleh permasalahan, dapat terlihat dari sikap individu yang kurang peduli terhadap persoalan yang sedang dihadapi bahkan mencoba melupakannya seolah-olah tidak pernah terjadi apa-apa (Lazarus, 1987). Penelitian menyebutkan bahwa cara mengatasi stressor dengan distancing memiliki hubungan yang signifikan dengan meningkatkan risiko depresi karena koping ini tidak segera menyelesaikan penyebab stressor yang dimilikinya dan cenderung lebih berpikir positif pada tiap stressor (Baqutayan, 2015).

Hasil penelitian menunjukkan 57,32\% caregiver tidak menggunakan Self-controlling dan $42,68 \%$ caregiver menggunakan selfcontrolling. Domain self-controlling merupakan suatu cara menghadapi stress dengan melakukan regulasi baik dalam perasaan maupun tindakan, dalam penyelesaian masalah akan selalu berfikir sebelum berbuat sesuatu dan menghindari untuk melakukan sesuatu tindakan secara tergesa-gesa (Lazarus, 1987). Penggunaan selfcontrolling untuk mengurangi tingkat stres dapat dilihat dari kapasitas individu dalam mengontrol diri. Individu yang memiliki kapasitas mengontrol diri yang buruk, menyebabkan tingkat kecemasan meningkat dan menyebabkan beban bagi individu. Cara yang dapat dilakukan untuk meningkatkan ketrampilan dalam meningkatkan selfcontroling dapat melalui edukasi maupun support group therapy cara mengedalikan diri (Boals, Vandellen, \& Banks, 2011).

Penelitian menunjukkan bahwa 53,66\% caregiver memilih menggunakan seeking social support. Domain seeking social support merupakan usaha untuk mencari dukungan dari pihak luar, baik berupa informasi, bantuan nyata, maupun dukungan emosional (Lazarus, 1987). Menggunakan seeking social support, caregiver dapat membangun hubungan sosial yang mampu memberikan dukungan profesional, emosional, dan memiliki seseorang yang dapat dipercayai untuk berbagi keluh kesah sehingga caregiver merasakan kepuasan yang lebih tinggi dan menurunkan depresi (Chen, Huang, Yeh, \& Chen, 2015).

Hasil penelitian menunjukkan bahwa $60,98 \%$ caregiver menggunakan acepting responsibility. Acepting responsibility merupakan cara individu dalam mengatasi stres dengan menerima segala sesuatu yang terjadi saat ini sebagai nama mestinya dan mampu menyesuaikan diri dengan kondisi yang sedang dialami (Lazarus, 1987). Penelitian menyebutkan individu yang menggunakan koping ini tidak berupaya untuk memperbaiki atau mengatasi penyebabnya dan lebih memilih untuk menyesuaikan diri dengan keadaan yang sedang dialaminya. Penggunaan acepting responsibility dibutuhkan ketika stressor sudah tidak mampu diatasi oleh individu, sehingga lebih memilih untuk menerima dan menyesuaikan diri dengan stressor (Smrtnik \& Prosen, 2016).

Analisa deskriptif domain escape avoidance menunjukkan bahwa $55,88 \%$ caregiver cenderung tidak menggunakan domain tersebut. Escape avoidance merupakan respon psikologi dengan menghindar dari masalah yang dihadapi, bahkan sering kali melibatkan 
diri kedalam perbuatan yang negatif seperti tidur terlalu lama, minum obat-obatan terlarang dan tidak mau bersosialisasi dengan orang lain (Lazarus, 1987). Penelitian yang dilakukan menyatakan bahwa dengan meminimalisisr pemilihan escape avoidance dalam merawat lansia demensia maka akan mengurangi tingkat beban yang dirasa caregiver. Hal ini dikarenakan dengan menghindari permasalahan, maka masalah tidak akan bisa terselesaikan dengan baik dan menyebabkan beban semakin bertambah (Huang et al., 2015). Analisa deskriptif domain positive reappraisal menunjukkan bahwa $58,54 \%$ caregiver menggunakan domain tersebut. Positive reappraisal adalah cara menghadapi stres dengan menciptakan makna positif yang bertujuan untuk mengembangkan diri termasuk melibatkan diri dalam hal-hal yang religius (Lazarus, 1987). Tingkat spiritualitas yang tinggi berpengaruh dalam aspek psikologis, kesehatan diri, dan dapat mengurangi beban. Penelitian menyatakan bahwa strategi koping dengan religius merupakan cara yang paling efektif dalam membantu masalah yang sudah tidak biasa dikendalikan dan dapat menimbulkan keputusasaan. Caregiver yang menggunakan koping ini biasanya memiliki tekanan psikologi yang lebih rendah (Rathier, Davis, Papandonatos, Grover, \& Tremont, 2015).

\section{SIMPULAN DAN SARAN}

Hasil penelitian yang sudah dilakukan didapatkan caregiver lansia demensia adalah mayoritas berusia 41-60 tahun, berjenis kelamin perempuan, tingkat pendidikan SMA/SMK, dan beragama Islam. Beban perawatan yang dialami caregiver yaitu beban ringan sebanyak $56,7 \%$, beban sedang sebanyak $24,4 \%$ dan caregiver mengalami beban berat sebanyak $16,6 \%$. Penggunaan strategi koping didapatkan $52,4 \%$ caregiver menggunakan PFC dengan domain yang paling sering digunakan yaitu planful problem dan 47,6\% caregiver menggunakan EFC dengan domain yang sering digunakan seeking social support, accepting responsibility, dan postive reappraisal. Intervensi dengan prinsip konseling, psychoeeducation, dan familyassociation menjadi dasar untuk meringankan beban yang dirasakan oleh caregiver. Saran bagi pemberi layanan khususnya perawat untuk dapat memberikan bimbingan konseling, psychoeeducation, dan familyassociation sehingga dapat menumbuhkan strategi koping yang efektif dan pelatihan cara merawat lansia demensia kepada caregiver.

\section{DAFTAR PUSTAKA}

Alfakhri, A. S., Alshudukhi, A. W., Alqahtani, A. A., Alhumaid, A. M., Alhathlol, O. A., Almojali, A. I., ... Alaqeel, M. K. (2018). Depression Among Caregivers of Patients With Dementia. INQUIRY: The Journal of Health Care Organization, Provision, and Financing, 55.

Ali S, B. I. (2015). Maladaptive cognitions and physical health of the caregivers of dementia: an interpretative phenomenologicala analysis. International Journal Qualitative Study Health Well-Being, 10(16).

Alzheimer's Association \& National Alliance for Caregiving. (2004). Families care: Alzheimer's caregiving in the United States.

Alzeimer's Disease International (2010). World Alzheimer Report 2010: the global economic impact of dementia. www. Alz.co.uk

Alzheimer's Disease International (ADI ). (2015). World alzheimer report 2015, the global economic impact of dementia. https://doi.org/DOI: $\quad 10.1111 /$ j.09637214.2004.00293.x.

Andrén, S., \& Elmståhl, S. (2007). Relationships between income, subjective health and caregiver burden in caregivers of people with dementia in group living care: A cross-sectional community-based study. International Journal of Nursing Studies, 44(3), 435446.

https://doi.org/10.1016/j.jinurstu.2006.0 8.016

Aschbacher K, Patterson TL, von Känel R, Dimsdale JE, Mills PJ, Adler KA, Ancoli-Israel S, G. I. (2005). Coping processes and hemostatic reactivity to 
acute stress in dementia caregivers. Psychosomatic Medicine, 67(6).

Ashley, N., Kleinpeter, R., \& Hagan, C. (2008). Gender differences in coping strategies of spousal dementia caregivers. Journal Gerontology and Geriatric Medicine, 37-41.

Azizah, L. M. (2011). Keperawatan lanjut usia. Yogyakarta: Graha Ilmu.

Baker, J. P., \& Berenbaum, H. (2008). The efficacy of problem focused and emotional approach interventions varies as a function of emotional processing style. Cognitive Therapy and Research, 32(1), 66-82.

Baqutayan, S. M. S. (2015). Stress and coping mechanisms: a historical overview. Mediterranean Journal of Social Sciences, 6(2), 479-488.

Boals, A., Vandellen, M. R., \& Banks, J. B. (2011). The relationship between selfcontrol and health: The mediating effect of avoidant coping. Pscychology \& Health, 26(8), 1049-1062.

Chen, H. M., Huang, M. F., Yeh, Y. C., \& Chen, C. S. (2015). Effectiveness of coping strategies intervention on caregiver burden among caregivers of elderly patients with dementia. Psychogeriatrics, 15(1), 20-25.

Fazio, S., Pace, D., Maslow, K., Zimmerman, S., \& Kallmyer, B. (2018). Alzheimer's Association Dementia Care Practice Recommendations. The Gerontologist, 58(suppl_1), S1-S9. https://doi.org/10.1093/geront/gnx182

Gottlieb, B.H., \& Wolfe, J. (2002). Coping with family caregiving to persons with dementia: A critical review. Aging and Mental Health, 6, 325-342.

Hogervorst, Tony Sajimin, Lindawati Kusdhany, Philip Kreager and Tri Budi Rahardjo, 2009. Hormones, Cognitive Function and Dementia (Book Chapter) Cambrige University Press
Huang, M. F., Huang, W. H., Su, Y. C., Hou, S.-Y., Chen, H.-M., Yeh, Y.-C., \& Chen, C.-S. (2015). Coping strategy and caregiver burden among caregivers of patients with dementia. American Journal of Alzheimer's Disease \& Other Dementias, 30(7), 694-698.

Jeffrey, S., \& Nevid, S. (2002). Psikologi abnormal (5th ed.). Jakarta: Penerbit Erlangga.

Kathleen Masters. (2015). Roy Adaptation Model: Sister Callista Roy. In Nursing Theories: A Framework for Professional Practice, Second Edition (Second, pp. 127-142). Jones \& Bartlett Learning.

Kim, M. D., Hong, S. C., Lee, C. I., Kim, S. Y., Kang, I. O., \& Lee, S. Y. (2009). Caregiver burden among caregivers of Koreans with dementia. Gerontology, 55(1) 106-113. https://doi.org/10.1159/000176300

Lazarus, F. (1987). Transactional theory and research on emotions and coping. Europe Journal Pers, 141-169.

Miller, C.A. (2004). Nursing for wellness in Older adult: Theory and Practice. 4th edition. Philadelphia: Lippincott Williams and Wilkins.

Miyamoto, Y., Tachimori, H., \& Ito, H. (2010). Formal Caregiver Burden in Dementia: Impact of Behavioral and Psychological Symptoms of Dementia and Activities of Daily Living. Geriatric Nursing, 31(4), 246-253. https://doi.org/10.1016/j.gerinurse.2010. 01.002

Mohamed S, Rosenheck R, \& Lyketsos K. (2014) . Caregiver Burden in Alzheimer's Disease: Cross Sectional and Longitudinal Patient Correlates. Am J Geriatr Psychiatry

Murtiyani, N., \& Haryani, R. (2010). Studi korelasi demensia dengan tingkat ketergantungan lansia dalam pemenuhan activities of daily living. Jurnal Keperawatan, 9, 41-48. 
Nagpal, N., Heid, A. R., Zarit, S. H., \& Whitlatch, C. J. (2015). Religiosity and quality of life: a dyadic perspective of individuals with dementia and their caregivers. Aging Mental Healthy, 19(6), 500-506.

Papastavrou, E., Tsangari, H., Karayiannis, G., Papacostas, S., Efstathiou, G., \& Sourtzi, P. (2011). Caring and coping: the dementia caregivers. Aging Mental Healthy, 15, 702-711.

Papastavrou, E., Kalokerinou, A., Papacostas, S. S., Tsangari, H., \& Sourtzi, P. (2007). Caring for a relative with dementia: Family caregiver burden. Journal of Advanced Nursing, 58(5), 446-457. https://doi.org/10.1111/j.13652648.2007.04250.x

Prabasari, N. A., Juwita, L., \& Maryuti, I. A. (2017). Pengalaman keluarga dalam merawat lansia di rumah (studi fenomenologi), 5(1), 56-68.

Putri, Y. S. E. (2013). Prediktor beban merawat dan tingkat depresi caregiver dalam merawat lanjut usia dengan demensia. Jurnal Ners, 8(1), 88-97.

Rathier, L. A., Davis, J. D., Papandonatos, G. D., Grover, C., \& Tremont, G. (2015). Religious coping in caregivers of family members with dementia. Journal of Applied Gerontology, 34(8), 977-1000.

Sugiyama, H., Kasanuki, K., Yamagata, M., Sato, N., \& Ichimiya, Y. (2017). Efficacy of group psychotherapy for caregivers of dementia patients. Alzheimer's \& Dementia: The Journal of the Alzheimer's Association, 13(7), P1558. https://doi.org/10.1016/j.jalz.2017.07.70 4

Sun, F., Kosberg, J. I., Leeper, J., Kaufman, A. V., \& Burgio, L. (2010). Racial differences in perceived burden of rural dementia caregivers: The mediating effect of religiosity. Journal of Applied Gerontology, 29(3), 290-307. https://doi.org/10.1177/0733464809343
Smrtnik, V. H., \& Prosen, S. (2016). Coping and emotion regulation strategies in adulthood: Specificities Regarding Age, Gender and Level of Education. Journal for General Social Issues (DRUS ISTRAZ), 25(1), 43-62.

Triwanti, S. P., \& Gutama, A. S. (2014). Meningkatkan kesejahteraan lansia. Social Work Journal, 4, 129-136.

Truong, Q. T. (2015). The quality of life and caregiving burden among of people with dementia in Hanoi, Bac Ninh and Hai Phong, Vietnam. Queensland Universityof Technology.

Watson, J. (2017). Caring for caregivers of individuals with dementia: from the perspective of watson's theory of human caring. Journal of Hacettepe University Faculty of Nursing, 4(1), 62-72.

Widyastuti,R.H.,Sahar,J.,\& Permatasari,H. (2011).Pengalaman keluarga merawat lansia dengan demensia. JURNAL NERS INDONESIA Vol(1), No 02.

World Report Alzheimer, 2012. Laporan Alzheimer Dunia Tahun 2012 Menyatakan Epidemis Alzheimer Sedunia Menyebabkan Keterbatasan Jumlah Para Perawat Dan Kekurangan Dukungan Bagi AnggotaKeluarga. http://www.alzheimerindonesia.org

Yuliawati AD. Handadari, W. (2013). Hubungan antara tingkat stres dengan tindak kekerasan pada caregiver lansia dengan demensia. Jurnal Psikologi Klinis Dan Kesehatan Mental, 2(1), 4853.

Yuniati, F. (2017). Pengalaman Caregiver dalam Merawat Lanjut Usia dengan Penurunan Daya Ingat. Jurnal Bahana Kesehatan Masyarakat, 1(1), 27-42.

Zarit, S.H., Reever, K.E., \& BachPeterson, J. (1980). Relatives of the impaired elderly: Correlates of 
feelings of burden. Gerontologist, 20, 649-655.

Zawadzki, L., Mondon, K., Peru, N., Hommet, C., Constans, T., Gaillard, P., \& Camus, V. (2011). Attitudes towards Alzheimer's disease as a risk factor for caregiver burden. International Psychogeriatrics, 23(9), 1451-1461. https://doi.org/10.1017/S104161021100 0640 